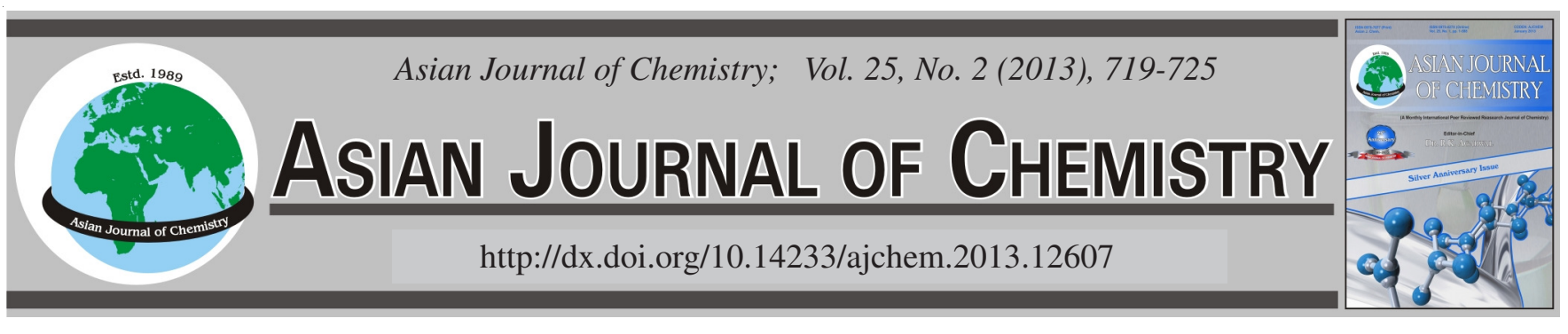

\title{
Spectrophotometric Bivariate Method for Determination of Candesartan Cilexetil in Presence of its Alkaline Induced Degradation Product
}

\author{
Nawal Al-Arfaj, Wedad Al-Onazi ${ }^{*}$ and Amina Al-Brashy
}

Department of Chemistry, College of Science, (Girls Section), King Saud University, P.O. Box 22452, Riyadh-11495, Saudi Arabia

*Corresponding author: E-mail: walonazi@yahoo.com

\begin{abstract}
A simple, sensitive, selective and precise stability -indicating method for the determination of candesartan cilexetil in presence of its alkaline degradate and in tablets was developed and validated. The method is based on determination of candesartan cilexetil by the bivariate calibration depending on simple mathematic algorithm which provide simplicity and rapidity. The method showed good linearity in the range of $1-12 \mu \mathrm{g} \mathrm{mL}^{-1}$ at 225 and $2-12 \mu \mathrm{g} \mathrm{mL}^{-1}$ at $250 \mathrm{~nm}$ with mean percentage recovery $100.29 \pm 0.64$. Candesartan cilexetil can be determined in the presence of up to $80 \%$ of its alkaline degradate, the selectivity of the method was checked using laboratory prepared mixtures. The proposed method has been successfully applied to the analysis of candesartan cilexetil in bulk and in commercial tablets without interference from additives or excipients and the results were satisfactory compared with a reference method. Also, the suggested method was successfully applied to the content uniformity testing and degradation kinetic study.
\end{abstract}

Key Words: Candesartan cilexetil, Candesartan, Stability-indicating, Bivariate method.

\section{INTRODUCTION}

Candesartan cilexetil belongs to the class of angiotensin receptor antagonists and acts by binding selectivity and noncompetitively to angiotensin II receptor type I, thus preventing actions of angiotensin II.

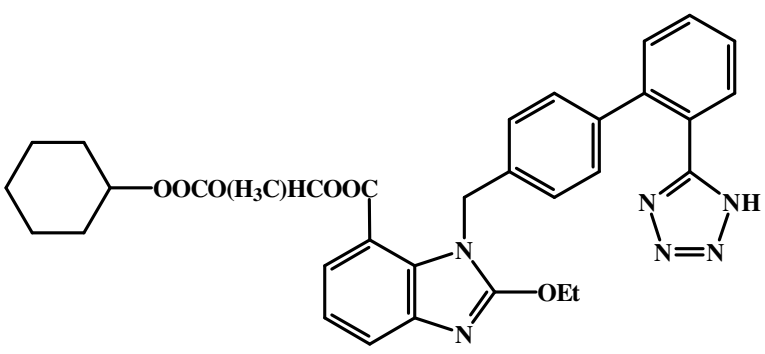

Candesartan cilexetil (CC); m.f. $\mathrm{C}_{33} \mathrm{H}_{34} \mathrm{~N}_{6} \mathrm{O}_{6}$; m.w. 610.67

The drug finds most significant clinical use in the treatment of hypertension of all grades ${ }^{1}$. Chemically, candesartan cilexetil is an ester prodrug of its active metabolite candesartan (C.V.11974), to which it owes its therapeutic effect, by the action of some endogenous esterases ${ }^{2}$.

The chemical stability of candesartan cilexetil has been studied in plasma and bioanalytical samples ${ }^{3}$. Under these conditions the drug was found to be susceptible to hydrolysis resulting the removal of cilexetil moiety. Few methods for the determination of candesartan cilexetil have been reported in literature. HPLC methods were reported for determination of candesartan cilexetil or candesartan with some angiotensin II receptor antagonists with or without hydrochlorothiazide as a diuretic drug ${ }^{4-6}$. Also, HPLC methods were reported for determination of candesartan cilexetil in tablets as a single component $^{3,7-9}$, in combination with candesartan and a metabolite (M II $)^{10}$ in human plasma and urine and with hydrochlorothiazide simultaneously in pharmaceutical formulations ${ }^{11-13}$.

Capillary electrophoresis methods were reported for simultaneous analysis of several angiotensin II receptor antagonists including candesartan cilexetil ${ }^{14-17}$. Other methods such as voltametry ${ }^{18-20}$ and HPTLC-densitometry ${ }^{21}$ were reported for determination of candesartan cilexetil.

The only spectrophotometric methods reported for determination of candesartan cilexetil were the first order derivative for it in tablets ${ }^{22}$ as a single component or simultaneously with hydrochlorothiazide ${ }^{23}$ or for simultaneous determination of candesartan and hydrochlorothiazide in tablets ${ }^{24}$.

No stability-indicating methods are reported in literature for determination of candesartan cilexetil in presence of its alkaline degraded product, candesartan. The scientific novelty of the present work is that the suggested spectrophotometric bivariate method is simple, rapid, selective, less expensive and 
less time consuming compared with other published chromatographic methods. The focus of the present work study was to develop and validate a simple stability - indicating method for determination of candesartan cilexetil in presence of its alkaline degradate (candesartan) for the quality control of candesartan cilexetil in its dosage forms.

\section{EXPERIMENTAL}

The spectrophotometric measurements were made with Ultrospec 2000, UV/VIS spectrophotometer, Amersham Pharmacia Biotech with Swift II Application, Biochrom Ltd, Cambridge UK. The solutions were recorded in $1 \mathrm{~cm}$ matched quartz cells against methanol as a solvent blank over the range 200-400 nm.

Pure standard: Candesartan cilexetil was kindly supplied from Jazeera Pharmaceutical Industries(JPI) Riyadh, Saudi Arabia. It was used as received without purification (its purity was $99.98 \%$ ).

Pharmaceutical dosage forms: Atacand 16 tablets, manufactured by AstraZeneca - Egypt under license of Astra Zeneca, Sweden. The Batch No. was 90123. Candesar 8 tablets, produced by PHARAONIA Pharmaceuticals, Pharo Pharma (Egypt), under license of Takeda Pharmaceutical Company Ltd. The Batch No. was 1409002.

Degraded product: $0.4 \mathrm{~g}$ of candesartan cilexetil powder was transferred into $250 \mathrm{~mL}$ stoppered flask, dissolved in $25 \mathrm{~mL}$ methanol, completed to $100 \mathrm{~mL}$ with $2 \mathrm{~N} \mathrm{NaOH}$ and refluxed with stirring at $80^{\circ} \mathrm{C}$ for $3 \mathrm{~h}$. Complete hydrolysis was followed via TLC using chloroform/methanol (80/20 $\mathrm{v} / \mathrm{v}$ ) as a developing system. The solution was neutralized with $4 \mathrm{~N} \mathrm{HCl}$ solution till $\mathrm{pH} 3$, then the degradate was extracted with chloroform $6 \mathrm{~mL} \times 20 \mathrm{~mL}$ ). The extract was evaporated at room temperature and the degradate powder was collected and elucidated by IR spectroscopy.

All chemicals used throughout this work (methanol, chloroform, $\mathrm{HCl}$ and $\mathrm{NaOH}$ ) were of $\mathrm{BDH}$, Poole, UK and the solvents were of spectroscopic grade.

Standard solutions: Stock standard solutions of candesartan cilexetil and its alkaline degradate containing $1 \mathrm{mg} \mathrm{mL}{ }^{-1}$ were prepared separately in methanol. Working solutions were prepared $\left(100 \mu \mathrm{g} \mathrm{mL}^{-1}\right)$ by suitably diluting the stock standard solutions.

Laboratory prepared mixtures: Solutions containing different ratios of candesartan cilexetil and its alkaline product were prepared to contain $20-80 \%$ of alkaline degradate.

\section{Procedure}

Construction of calibration graphs for the bivariate spectrophotometric method: Into two separate sets of $10 \mathrm{~mL}$ volumetric flasks, aliquots equivalent to $10-120 \mu \mathrm{g} \mathrm{mL} \mathrm{m}^{-1}$ of candesartan cilexetil and its alkaline degradate were transferred from their working solutions $\left(100 \mu \mathrm{g} \mathrm{mL}^{-1}\right)$ in methanol. The volume was completed with methanol. The regression equations, at 225 and $250 \mathrm{~nm}$, for candesartan cilexetil and its alkaline degradate were computed.

Analysis of bulk substance: The method mentioned above was applied to the determination of the purity of candesartan cilexetil raw material and the percent recoveries were calculated by application in the bivariate equations.
Analysis of pharmaceutical dosage forms: Fourteen tablets of each i.e., Candesar- 8 tablets and Atacand-16 tablets were powdered and mixed well; an accurately weighed amount of the powder equivalent to $50 \mathrm{mg}$ of candesartan cilexetil of each was transferred into two separate $100 \mathrm{~mL}$ volumetric flasks. $75 \mathrm{~mL}$ of methanol were added, sonicated for $0.5 \mathrm{~h}$, completed to volume with methanol, to obtain $0.5 \mathrm{mg} / \mathrm{mL}$ stock solution and filtered. The solution was diluted to the same concentrations of the appropriate working solutions and proceeded according to the procedure mentioned above. The nominal content of candesartan cilexetil in each tablets was calculated from application in the bivariate equations.

Content uniformity testing: The same procedure applied for the analysis of candesartan cilexetil in tablets was followed using one tablet as a sample. Ten tablets were analyzed and the uniformity of their contents was tested by applying the official of USP guidelines.

Stability study of the degradation products: A stock solution of $400 \mathrm{mg} / \mathrm{mL}$ of candesartan cilexetil was prepared in methanol. Aliquots of this solution $\left(10 \mu \mathrm{g} \mathrm{mL}^{-1}\right)$ were transferred into $10 \mathrm{~mL}$ volumetric flasks, $3 \mathrm{~mL}$ aliquots of $0.1 \mathrm{M}$ $\mathrm{NaOH}$ or $0.1 \mathrm{M} \mathrm{HCl}$ were added. These volumetric flasks were placed in thermostated water bath at different temperatures $\left(50,70,80,90^{\circ} \mathrm{C}\right)$ for different time intervals $(10,20,30 \mathrm{~min})$.

At the specified time intervals, the content of each flask were cooled, neutralized to $\mathrm{pH} 7$ using predetermined volumes of $0.1 \mathrm{M} \mathrm{HCl}$ or $0.1 \mathrm{M} \mathrm{NaOH}$. The volume was completed to the mark with methanol and analyzed by the bivariate method as before.

\section{RESULTS AND DISCUSSION}

Candesartan is marketed as the cyclohexyl 1-hydroxyethyl carbonate (cilexetil) ester, known as candesartan cilexetil. Candesartan cilexetil is metabolized completely by esterases in the intestinal wall during absorption to the active candesartan moiety (the use of a prodrug form increases the bioavailability of candesartan). Upon refluxing candesartan cilexetil with alkali, the carboxylic acid (candesartan) was obtained.

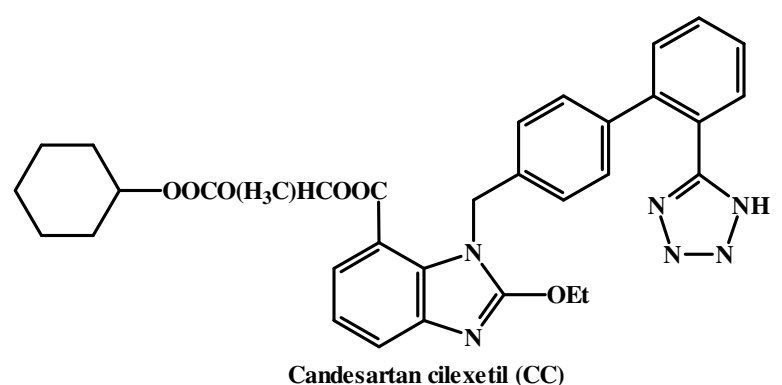

Candesartan cilexetil $(\mathrm{CC})$

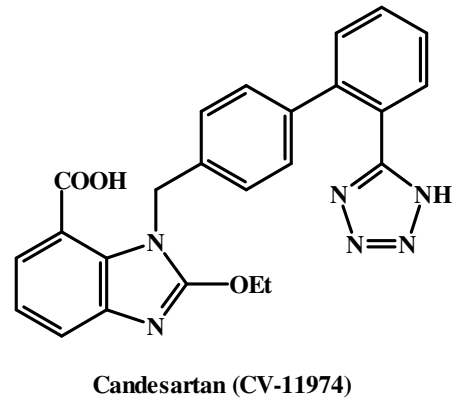


So the determination of candesartan cilexetil in presence of its alkaline degradation was essential.

The International Conference on Harmonization (ICH) guideline entitled "stability testing of new drugs substances and products" requires the stress testing to be carried out to elucidate the inherent stability characteristics of the active substances $^{25}$. An ideal stability- indicating method is one that quantifies the standard drug alone and also resolves its degradation products. The structure of the alkaline degradate was elucidated by IR. The IR spectrum of candesartan cilexetil showed a characteristic band at $1750 \mathrm{~cm}^{-1}$, indicating the presence of carbonyl group while the IR spectrum of the degradate showed the same band but shifted to $1705 \mathrm{~cm}^{-1}$ and a new broad band at $3388 \mathrm{~cm}^{-1}$ indicating the presence of a hydroxyl group of the carboxylic acid (due to hydrolysis, Fig. 1). Only one spot of the degraded product seen on TLC under UV lamp $(254 \mathrm{~nm})$ with $R_{\mathrm{f}}=0.24\left(\mathrm{R}_{\mathrm{f}}\right.$ for candesartan cilexetil was 0.78$)$.
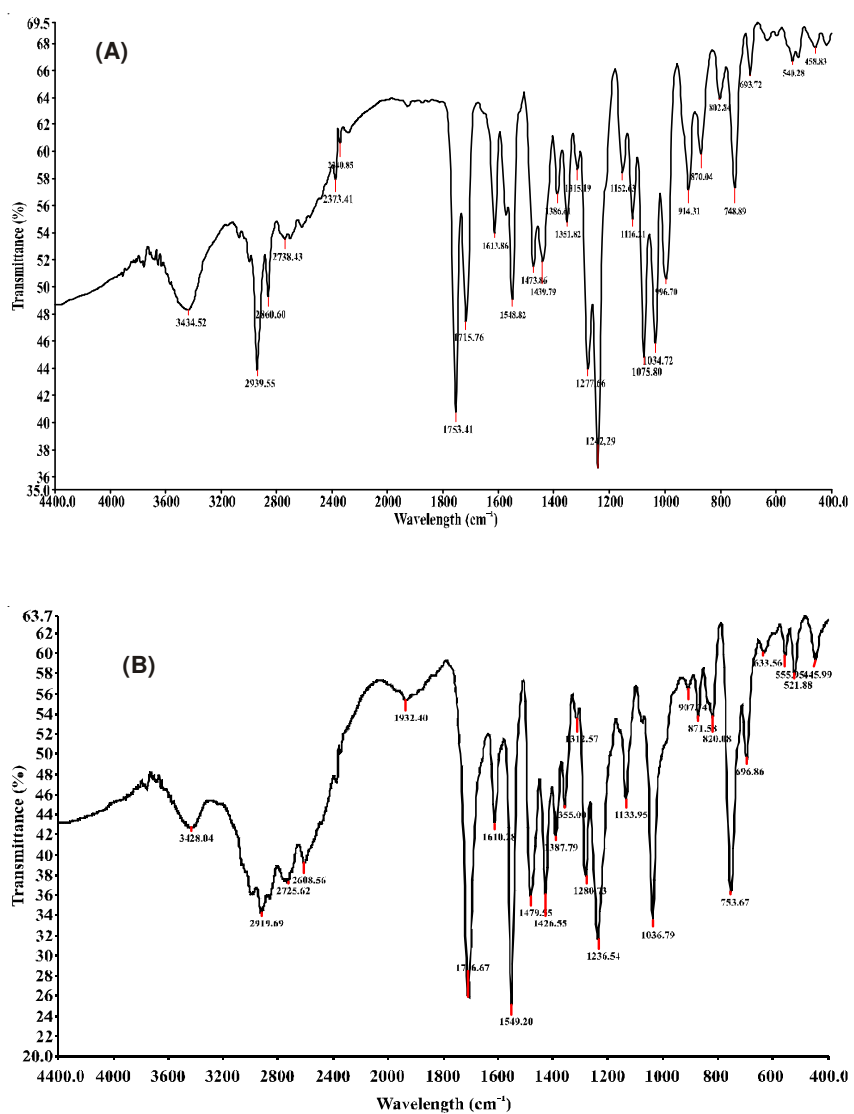

Fig. 1. IR spectra of candesartan cilexetil (A) and its degradation product candesartan (B) in methanol

The focus of the present work was to develop an accurate, specific, reproducible and sensitive stability-indicating method for the determination of candesartan cilexetil in presence of degradation product.The zero order absorption spectra of candesartan cilexetil and its alkaline degradate showed similarity and severe over-lapping (Fig. 2) which interfere with the direct determination of candesartan cilexetil. In the present work, candesartan cilexetil was determined and resolved from its alkaline degradate by using the bivariate calibration spectrophotometric method ${ }^{26,27}$. The method is based on a simple mathematic algorithm, in which the data used derives from four linear regression calibration equations: Two calibrations for each component at two wavelengths selected using the method of Massart et al. ${ }^{28}$. The method has been successfully applied to resolve different binary mixtures, such as nifuroxazide and drotaverine $\mathrm{HCl}^{29}$. The advantages of bivariate calibration method is its simplicity and the fact that derivatization procedures are not necessary; unlike other chemometric techniques, there is no need for full spectrum information and no data processing is required.

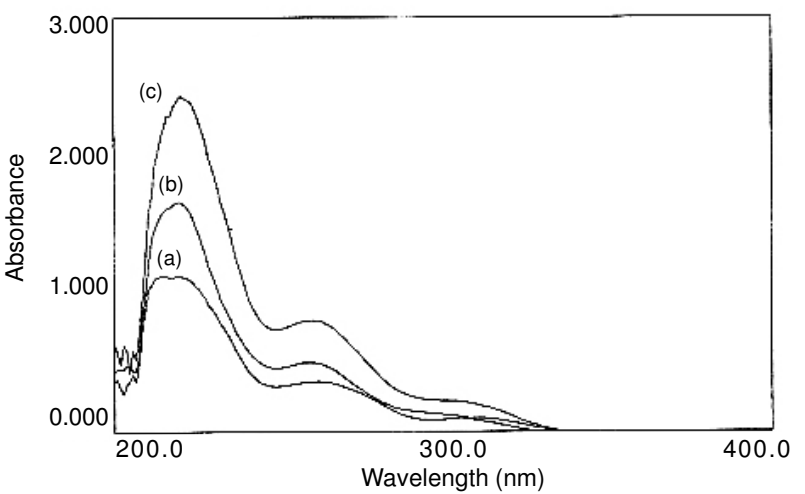

Fig. 2. Absorption spectra of candesartan cilexetil (a), candesartan (b) 10 $\mu \mathrm{g} \mathrm{mL} \mathrm{m}^{-1}$ each in methanol and their mixture (c)

The linear calibration regression function for the spectrophotometric determination of an analyte A, at a selected wavelength (i) is given by:

$$
\mathrm{A}_{\mathrm{A}_{\mathrm{i}}}=\mathrm{m}_{\mathrm{A}_{\mathrm{i}}} \cdot \mathrm{C}_{\mathrm{A}}+\mathrm{e}_{\mathrm{A}_{\mathrm{i}}}
$$

where $m_{A_{i}}$ is the slope of linear regression, $C_{A}$ is the concentration of analyte $A$ and $e_{A_{i}}$ is the intercept value. If the measurements for the binary mixture $(\mathrm{A}, \mathrm{B})$ are performed at two selected wavelengths $\left(\lambda_{1}, \lambda_{2}\right)$ we have a two equations set:

$$
\begin{aligned}
& \mathrm{A}_{\mathrm{AB}_{1}}=\mathrm{m}_{\mathrm{A}_{1}} \mathrm{C}_{\mathrm{A}}+\mathrm{m}_{\mathrm{B}_{1}} \mathrm{C}_{\mathrm{B}}+\mathrm{e}_{\mathrm{AB}_{1}} \\
& \mathrm{~A}_{\mathrm{AB}_{2}}=\mathrm{m}_{\mathrm{A}_{2}} \mathrm{C}_{\mathrm{A}}+\mathrm{m}_{\mathrm{B}_{2}} \mathrm{C}_{\mathrm{B}}+\mathrm{e}_{\mathrm{AB}_{2}}
\end{aligned}
$$

The resolution of such equations set allows the evaluation of $\mathrm{C}_{\mathrm{A}}$ and $\mathrm{C}_{\mathrm{B}}$ values:

$$
\begin{gathered}
\mathrm{C}_{\mathrm{A}}=\frac{\mathrm{m}_{\mathrm{B}_{2}}\left(\mathrm{~A}_{\mathrm{AB}_{1}}-\mathrm{e}_{\mathrm{AB}_{1}}\right)+\mathrm{m}_{\mathrm{B}_{1}}\left(\mathrm{e}_{\mathrm{AB}_{1}}-\mathrm{A}_{\mathrm{AB}_{2}}\right)}{\mathrm{m}_{\mathrm{B}_{2}} \mathrm{~m}_{\mathrm{A}_{1}}-\mathrm{m}_{\mathrm{B}_{1}} \mathrm{~m}_{\mathrm{A}_{2}}} \\
\mathrm{C}_{\mathrm{B}}=\frac{\mathrm{A}_{\mathrm{AB}_{1}}-\mathrm{e}_{\mathrm{AB}_{1}}-\mathrm{m}_{\mathrm{A}_{1}} \mathrm{C}_{\mathrm{A}}}{\mathrm{m}_{\mathrm{A}_{1}}}
\end{gathered}
$$

where $e_{\mathrm{AB}_{1}}$ and $\mathrm{e}_{\mathrm{AB}_{2}}$ are the sum of the intercepts of the linear calibration regression equations at the selected two wavelengths $\left(\mathrm{e}_{\mathrm{AB}_{1}}=\mathrm{e}_{\mathrm{A}_{1}}+\mathrm{e}_{\mathrm{B}_{1}}\right), \mathrm{m}_{\mathrm{A}}$ and $\mathrm{m}_{\mathrm{B}}$ are the slopes of the linear regression equations at the two selected wavelengths and $\mathrm{C}$ is the concentration of candesartan cilexetil and its alkaline degradate.

These simple mathematic algorithms allow the resolution of the two compounds by measuring the absorbance of candesartan cilexetil and its degradate at the two wavelengths and using the parameters of the linear regression functions evaluated individually for each component at the same 
TABLE-1

APPLICATION OF THE METHOD OF KAISER FOR THE SELECTION OF THE WAVELENGTH SET FOR THE DETERMINATION OF CANDESARTAN CILEXETIL

\begin{tabular}{ccccccccccc}
\hline$\lambda_{1} / \lambda_{2}$ & 225 & 230 & 235 & 240 & 245 & 250 & 255 & 260 & 265 \\
\hline 225 & 0 & 13.24 & 33.19 & 38.19 & 37.96 & 40.60 & 38.18 & 30.30 & 14.0 \\
230 & - & 0 & 18.58 & 23.80 & 23.70 & 25.37 & 23.30 & 17.50 & 5.5 \\
235 & - & - & 0 & 6.08 & 6.10 & 6.62 & 4.90 & 1.33 & 5.8 \\
240 & - & - & - & 0 & 0.13 & 1.77 & 1.32 & 4.03 & 9.28 \\
245 & - & - & - & - & 0 & 0.43 & 1.44 & 4.1 & 9.27 \\
250 & - & - & - & - & - & 0 & 1.56 & 4.42 & 9.9 \\
255 & - & - & - & - & - & - & 0 & 2.97 & 8.79 \\
260 & - & - & - & - & - & - & - & 0 & 5.89 \\
265 & - & - & - & - & - & - & - & - & 0 \\
\hline
\end{tabular}

The absolute values of determinations of sensitivity $\left(\mathrm{K} \times 10^{-5}\right)$. The bold value represent the highest matrix determinant value obtained at the wavelength set 225 and 250 .

wavelengths. The method of Massart et al. ${ }^{28}$ was used for the selection of optimum wavelength set which assured the best sensitivity for the quantitative determination of the cited drug. In order to apply this method, select the signals of the two components locate $(225,230,235,240,245,250,255,260$ and $265 \mathrm{~nm}$ ) wavelengths. The calibration curve equations and their respective linear regression coefficients are obtained directly with the aim of ensuring the linearity between the signal and the concentrations. The slope values of the linear regression were estimated for the drug and its alkaline degradate at the selected wavelengths and used for the determination of the sensitivity matrices K, proposed by Massart et $a l^{28}$. A series of sensitivity matrices $\mathrm{K}$, were calculated for each binary mixture and for every pair of the pre-selected wavelengths:

$$
\mathrm{K}=\left(\begin{array}{ll}
\mathrm{m}_{\mathrm{B}_{1}} & \mathrm{~m}_{\mathrm{A}_{1}} \\
\mathrm{~m}_{\mathrm{B}_{2}} & \mathrm{~m}_{\mathrm{A}_{2}}
\end{array}\right) \quad(\mathrm{A} \text { is } \mathrm{CC}, \mathrm{B} \text { is the degradate })
$$

where $m_{A_{1,2}}$ and $m_{B_{1,2}}$ are the sensitivity parameters (slope) of the regression equations of $\mathrm{A}$ and $\mathrm{B}$ at the two selected wavelengths $(225,250 \mathrm{~nm})$. The determinants of these matrices were calculated and shown in Table-1. The wavelength set was selected for which the highest matrix determinant value was obtained.

For bivariate determination of candesartan cilexetil in presence of its degradate, 225 and $250 \mathrm{~nm}$ were used; at these selected wavelengths the one-component calibration curves were obtained in the range of $2-12 \mu \mathrm{g} \mathrm{mL} \mathrm{m}^{-1}$ for candesartan cilexetil and its alkaline degradate, using the following linear regression calibration formula:

$$
\text { For } \begin{aligned}
\mathrm{CC} \mathrm{A} & =0.0037+0.0623 \mathrm{C}(\mathrm{r}=0.9997) \text { at } 225 \mathrm{~nm} \\
\mathrm{~A} & =0.0005+0.030 \mathrm{C}(\mathrm{r}=0.9992) \text { at } 250 \mathrm{~nm}
\end{aligned}
$$

For Deg. $\mathrm{A}=0.0043+0.0763 \mathrm{C}(\mathrm{r}=0.9999)$ at $225 \mathrm{~nm}$ $\mathrm{A}=0.0067+0.0414 \mathrm{C}(\mathrm{r}=0.9996)$ at $250 \mathrm{~nm}$

where $\mathrm{A}$ is the absorbance at the selected wavelength, $\mathrm{C}$ is the concentration in $\mu \mathrm{g} \mathrm{mL}^{-1}$ and (r) is the regression coefficient.

Different solvents were tried to resolve their overlapping as methanol, ethanol, butanol, acetonitrile, $0.05 \mathrm{~N} \mathrm{NaOH}$ and $0.05 \mathrm{~N} \mathrm{HCl}$, the best regression calibration lines were obtained in methanol solvent.

\section{Validation of the method}

Concentration ranges and calibration graphs: Under the above described experimental conditions, linear relation- ship were established by plotting the concentration of candesartan cilexetil and the alkaline degradate against absorbance at 225 and $250 \mathrm{~nm}$ in the range of $1-12 \mu \mathrm{gL}^{-1}$ for $225 \mathrm{~nm}$ and $2-12 \mu \mathrm{g} \mathrm{mL} \mathrm{L}^{-1}$ at $250 \mathrm{~nm}$. The high values of correlation coefficient (r) and small intercepts indicate good linearity of the calibration graphs. Statistical analysis of the candesartan cilexetil data gave small values of the standard deviation of the residuals $\left(\mathrm{S}_{\mathrm{Y} / \mathrm{X}}\right)$, of slop $\left(\mathrm{S}_{\mathrm{b}}\right)$, of intercept $\left(\mathrm{S}_{\mathrm{a}}\right)$ and the RSD (\%) and relative error (\%) (Er \%) (Table-2).

\begin{tabular}{lcc}
\multicolumn{3}{c}{ TABLE-2 } \\
\multicolumn{3}{c}{ PERFORMANCE DATA OF THE PROPOSED } \\
\multicolumn{3}{c}{ BIVARIATE METHOD FOR THE DETERMINATION } \\
OF CANDESARTAN CILEXETIL \\
\cline { 2 - 3 } \multicolumn{1}{c}{ Parameter } & \multicolumn{2}{c}{ Values } \\
\cline { 2 - 3 } \multicolumn{1}{c}{ At $225 \mathrm{~nm}$} & At $250 \mathrm{~nm}$ \\
\hline Range & $1-12 \mu \mathrm{L} \mathrm{L}^{-1}$ & $2-12 \mu \mathrm{mL}^{-1}$ \\
Slope & 0.0623 & 0.03 \\
Intercept & 0.0037 & 0.0005 \\
Correlation coefficient & 0.9997 & 0.9992 \\
LOD & 0.28 & 0.42 \\
LOQ & 0.86 & 1.27 \\
$\mathrm{~S}_{\mathrm{y} / \mathrm{x}}$ (Standard deviation of residuals $)$ & $7.4039 \times 10^{-4}$ & $1.397 \times 10^{-4}$ \\
$\mathrm{~S}_{\mathrm{a}}$ (Standard deviation of intercept) & 0.0038 & 0.00535 \\
$\mathrm{~S}_{\mathrm{b}}$ (Standard deviation of slope) & $7.4039 \times 10^{-4}$ & $5.26356 \times 10^{-4}$ \\
\hline
\end{tabular}

Limit of quantitation (LOQ) and limit of detection (LOD): The limit of quantitation was determined by establishing the lowest concentration that can be measured according to ICH Q 2 B recommendation ${ }^{30}$ below which the calibration graph is none linear and the limit of detection was determined by establishing the minimum level at which the analyte can be reliably detected $(\mathrm{S} / \mathrm{N}=3)$. The values are demonstrated in Table-2.

Accuracy and precision: The proposed method was evaluated by studying the accuracy as percent relative error (Er \%) and precision as percent relative standard deviation (RSD \%) using three preparations with suitable concentration, as shown in Table-3, the intraday $(\mathrm{n}=3)$ and interday $(\mathrm{n}=3)$ accuracy calculated as error (\%) was found to be $0.36-0.47$ and $0.22-0.33 \%$ for candesartan cilexetil, respectively. The repeatability of the assay was found to be within 0.63-0.82\% $(\mathrm{n}=3)$ at 4,8 and $12 \mu \mathrm{g} \mathrm{mL} \mathrm{m}^{-1}$. The reproducibility of the assay at the same concentration levels was found to be $0.38-0.65 \%$ $(n=3)$. 


\begin{tabular}{lccc}
\hline \multicolumn{4}{c}{ TABLE-3 } \\
ACCURACY AND PRECISION DATA FOR CANDESARTAN \\
CILEXETIL USING THE PROPOSED BIVARIATE METHOD \\
\hline \multirow{2}{*}{ Parameter } & \multicolumn{3}{c}{ CC concentration $\left(\mu \mathrm{g} \mathrm{mL}^{-1}\right)$} \\
\cline { 2 - 4 } & 4 & 8 & 12 \\
\hline Intraday \% recovery & 99.52 & 100.28 & 101.08 \\
& 100.60 & 98.98 & 99.55 \\
Mean \pm SD & 99.49 & 99.76 & 100.80 \\
RSD $(\%)$ & $99.87 \pm 0.63$ & $99.67 \pm 0.65$ & $100.48 \pm 0.82$ \\
Er $(\%)$ & 0.63 & 0.65 & 0.81 \\
\hline Interday \% recovery & 0.36 & 0.38 & 0.47 \\
& 101.14 & 98.74 & 99.61 \\
& 100.06 & 99.77 & 100.10 \\
Mean \pm SD & 100.28 & 99.93 & 100.35 \\
RSD $(\%)$ & $100.49 \pm 0.57$ & $99.48 \pm 0.65$ & $100.02 \pm 0.38$ \\
Er $(\%)$ & 0.57 & 0.65 & 0.38 \\
\hline NB: Each result & 0.33 & 0.38 & 0.22 \\
\hline
\end{tabular}

NB: Each result is the average of three separate determinations. Intraday: within the day. Interday: consecutive days.

\section{Applications}

Determination of candesartan cilexetil bulk material: The results of the proposed method for determination of the purity of candesartan cilexetil were favourably compared with those obtained using the reference method ${ }^{22}$. The latter method depends on measuring the first derivative $\left(\mathrm{D}^{1}\right)$ of candesartan cilexetil, as a single component at $270 \mathrm{~nm}$. Statistical analysis of the results obtained by the proposed and reference methods showed no significant differences in the performance of the 2 methods using the Student's $t$-test and Variance ratio, F-test $(\text { Table- } 4)^{31}$. The proposed procedure offers additional advantages over the reference procedure in that the proposed is more sensitive with good accuracy and precision and considered as a stability-indicating method for determination of candesartan cilexetil in presence of its alkaline degradation product.

Analysis of laboratory prepared mixtures: The absorption spectra of different prepared mixtures were measured at 225 and $250 \mathrm{~nm}$, the concentration of candesartan cilexetil was calculated using the parameters of the linear regressions function evaluated for candesartan cilexetil and its degradate at the same wavelengths and substituting in the previous equations for $\mathrm{C}_{\mathrm{A}}$ and $\mathrm{C}_{\mathrm{B}}$. The results obtained in Table- 5 showed that the method is valid for the determination of candesartan cilexetil in presence of up to $80 \%$ of its alkaline degradate.

Tablet analysis: The proposed bivariate method was applied to the determination of candesartan cilexetil in its

\begin{tabular}{|c|c|c|c|c|}
\hline \multicolumn{5}{|c|}{$\begin{array}{c}\text { TABLE-5 } \\
\text { DETERMINATION OF CANDESARTAN CILEXETIL IN } \\
\text { LABORATORY PREPARED MIXTURES BY THE PROPOSED } \\
\text { BIVARIATE SPECTROPHOTOMETRIC METHOD }\end{array}$} \\
\hline \multicolumn{2}{|c|}{ Alkaline product } & \multicolumn{3}{|c|}{ Candesartan cilexetil } \\
\hline $\begin{array}{c}\text { Added } \\
\left(\mu \mathrm{g} \mathrm{mL} L^{-1}\right)\end{array}$ & $\%$ & $\begin{array}{c}\text { Taken }(\mu \mathrm{g} \\
\left.\mathrm{mL}^{-1}\right)\end{array}$ & $\begin{array}{c}\text { Found ( } \mu \mathrm{g} \\
\mathrm{mL}^{-1} \text { ) }\end{array}$ & Found (\%) \\
\hline 2 & 20 & 8 & 7.994 & 99.93 \\
\hline 4 & 40 & 6 & 5.938 & 98.97 \\
\hline 6 & 50 & 6 & 6.050 & 100.83 \\
\hline 6 & 60 & 4 & 3.986 & 99.65 \\
\hline 8 & 80 & 2 & 2.016 & 100.80 \\
\hline Mean \pm SD & - & - & - & $100.04 \pm 0.79$ \\
\hline
\end{tabular}

N.B. Each result is the average of three separate determinations.

commercial tablets, the results were shown in Table-6. The validity of the method was assessed by applying the standard addition technique (Table-7), the results of analysis of the commercial tablets and the recovery study (standard addition method) suggested that there are no interference from any excipients which are normally present in tablet formulations. The results for the determination of candesartan cilexetil in tablets obtained by the proposed method were compared with the $\mathrm{D}^{1}$ method $^{22}$. Statistical analysis of the results was performed with regard to accuracy and precision using student ' $t$-test and F- ratio; as presented in Table-6, there is no significant difference between the proposed and the reference methods with regard to accuracy and precision ${ }^{31}$.

Content uniformity testing: Due to the high precision of the proposed method and its ability to rapidly estimate the concentration of $\mathrm{CC}$ in a single tablet extract with sufficient accuracy, the method is ideally suited for content uniformity testing which is a time consuming process when using conventional assay techniques. The steps of the test were adopted according to the USP ${ }^{32}$ procedure. The acceptance value (AV) was calculated for each of the commercially available tablets and it was found to be smaller than the maximum allowed acceptance value (LI). The results demonstrated excellent drug uniformity, as shown in Table-8.

Degradation kinetic study: Degradation of candesartan cilexetil with either $\mathrm{NaOH}$ or $\mathrm{HCl}$ was found to be temperature dependent (Fig. 3). The apparent first order degradation rate content and $\mathrm{t}_{1 / 2}$ times at each temperature were calculated for $\mathrm{NaOH}$ degradation and given in Table-9. Plotting $\ln \mathrm{K}$ observed values versus 1/T, Arrhenius plot was obtained (Fig. 4).

TABLE-4

STATISTICAL ANALYSIS OF THE RESULTS OBTAINED BY THE PROPOSED AND REFERENCE METHODS

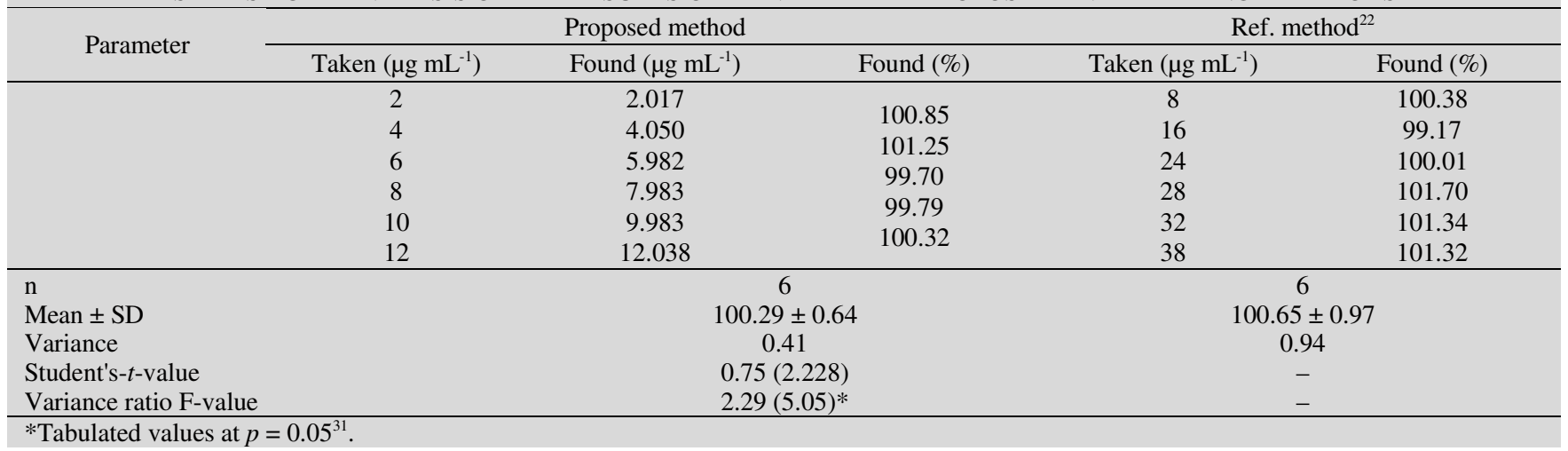




\begin{tabular}{|c|c|c|c|c|c|}
\hline \multirow{2}{*}{ Parameter } & \multicolumn{3}{|c|}{ Proposed method } & \multicolumn{2}{|c|}{ Ref. method ${ }^{22}$} \\
\hline & Taken $\left(\mu \mathrm{g} \mathrm{mL}^{-1}\right)$ & Found $\left(\mu \mathrm{g} \mathrm{mL} L^{-1}\right)$ & Found $(\%)$ & Taken $\left(\mu \mathrm{g} \mathrm{mL}^{-1}\right)$ & Found $(\%)$ \\
\hline Atacand-16 & 6 & 5.991 & 99.85 & 10 & 99.35 \\
\hline \multirow{3}{*}{ Tablets } & 8 & 8.034 & 100.43 & 16 & 99.47 \\
\hline & 10 & 9.967 & 99.67 & 24 & 100.43 \\
\hline & 12 & 12.032 & 100.27 & 30 & 100.70 \\
\hline Mean \pm SD & - & - & $100.06 \pm 0.35$ & - & $99.99 \pm 0.68$ \\
\hline Student's- $t$-value & - & 0.13 & - & - & - \\
\hline Variance ratio F-value & - & 3.77 & - & - & - \\
\hline \multicolumn{6}{|l|}{ Candesar-8 } \\
\hline \multirow{4}{*}{ Tablets } & 6 & 6.046 & 100.77 & 10 & 99.88 \\
\hline & 8 & 7.938 & 99.23 & 16 & 100.70 \\
\hline & 10 & 10.033 & 100.33 & 20 & 100.35 \\
\hline & 12 & 11.926 & 99.38 & 30 & 100.57 \\
\hline Mean \pm SD & - & - & $99.93 \pm 0.74$ & - & $100.13 \pm 0.63$ \\
\hline Student's- $t$-value & - & 0.41 & - & - & - \\
\hline Variance ratio F-value & - & 1.38 & - & - & - \\
\hline
\end{tabular}

N. N.B. Each result is the average of three separate determinations. Tabulated $t$-test and F test are 2.45 and 9.28 at $p=0.05$, respectively ${ }^{31}$.

\section{TABLE-7}

ASSAY OF CANDESARTAN CILEXETIL IN FORMULATION BY APPLICATION OF STANDARD ADDITION METHOD USING THE PROPOSED BIVARIATE METHOD

\begin{tabular}{lcccc}
\hline Preparation & $\begin{array}{c}\text { Amt. taken } \\
\left(\mu \mathrm{g} \mathrm{mL}^{-1}\right)\end{array}$ & $\begin{array}{c}\mathrm{CC} \text { added } \\
\left(\mu \mathrm{g} \mathrm{mL}^{-1}\right)\end{array}$ & $\begin{array}{c}\text { Amt found } \\
\left(\mu \mathrm{g} \mathrm{mL}^{-1}\right)\end{array}$ & Found $(\%)$ \\
\hline Atacand-16 & 2 & 4 & 5.968 & 99.47 \\
Tablets & 4 & 6 & 9.971 & 99.71 \\
& 6 & 2 & 7.905 & 98.81 \\
& 6 & 6 & 12.016 & 100.13 \\
Mean \pm SD & - & - & - & $99.53 \pm 0.55$ \\
\hline Candesar-8 & 2 & 4 & 5.953 & 99.22 \\
Tablets & 4 & 6 & 9.843 & 98.43 \\
& 6 & 2 & 7.936 & 99.20 \\
& 6 & 6 & 12.018 & 100.15 \\
Mean \pm SD & - & - & - & $99.25 \pm 0.70$ \\
\hline
\end{tabular}

N.B. Each result is the average of three separate determinations.

\begin{tabular}{|c|c|c|}
\hline \multicolumn{3}{|c|}{$\begin{array}{c}\text { TABLE-8 } \\
\text { RESULTS OF CONTENT UNIFORMITY TESTING OF } \\
\text { CANDESARTAN CILEXETIL TABLETS USING } \\
\text { THE PROPOSED BIVARIATE METHOD }\end{array}$} \\
\hline \multirow{2}{*}{ Parameter } & \multicolumn{2}{|c|}{ Percentage of the label claim } \\
\hline & Candesar 8 & Atacand 16 \\
\hline \multirow{10}{*}{ Data } & 99.51 & 100.55 \\
\hline & 101.14 & 99.49 \\
\hline & 100.22 & 98.98 \\
\hline & 99.55 & 100.60 \\
\hline & 100.94 & 100.54 \\
\hline & 99.52 & 100.35 \\
\hline & 98.74 & 99.76 \\
\hline & 99.77 & 100.12 \\
\hline & 99.93 & 101.08 \\
\hline & 100.54 & 99.61 \\
\hline Mean \pm SD & $99.99 \pm 0.73$ & $100.11 \pm 0.64$ \\
\hline $\operatorname{RSD}(\%)$ & 0.73 & 0.64 \\
\hline Error $(\%)$ & 0.23 & 0.20 \\
\hline Acceptance value $(\mathrm{AV})^{32}$ & 1.75 & 1.54 \\
\hline Max allowed AV (LI) ${ }^{32}$ & 15 & $(\mathrm{AV})^{32}$ \\
\hline
\end{tabular}

Arrhenius equation was found to be:

$$
\ln \mathrm{K}=2.747-5.025 \times 10^{-3} / \mathrm{T}
$$

where $\mathrm{K}$ is the rate constant and $\mathrm{T}$ is the temperature in Kelvin.
TABLE-9

EFFECT OF TEMPERATURE ON THE KINETICPARAMETERS OF CANDESARTAN CILEXETIL USING $0.1 \mathrm{M} \mathrm{NaOH}$

\begin{tabular}{ccccc}
\hline Medium & $\begin{array}{c}\text { Temp. } \\
\left({ }^{\circ} \mathrm{C}\right)\end{array}$ & $\begin{array}{c}\mathrm{K} \\
\left(\mathrm{min}^{-1}\right)\end{array}$ & $\begin{array}{c}\mathrm{T}_{1 / 2} \\
(\mathrm{~min})\end{array}$ & $\begin{array}{c}\mathrm{E}_{\mathrm{a}}(\mathrm{Kcal} \\
\left.\mathrm{mol}^{-1}\right)\end{array}$ \\
\hline \multirow{2}{*}{$\bar{O}$} & 60 & 0.011 & 62.43 & 10.53 \\
\hdashline $\bar{\sigma}$ & 70 & 0.0175 & 39.60 & 9.52 \\
& 80 & 0.026 & 26.65 & 10.19 \\
& 90 & 0.0388 & 17.86 & $\mathrm{X}=10.08$ \\
\hline
\end{tabular}

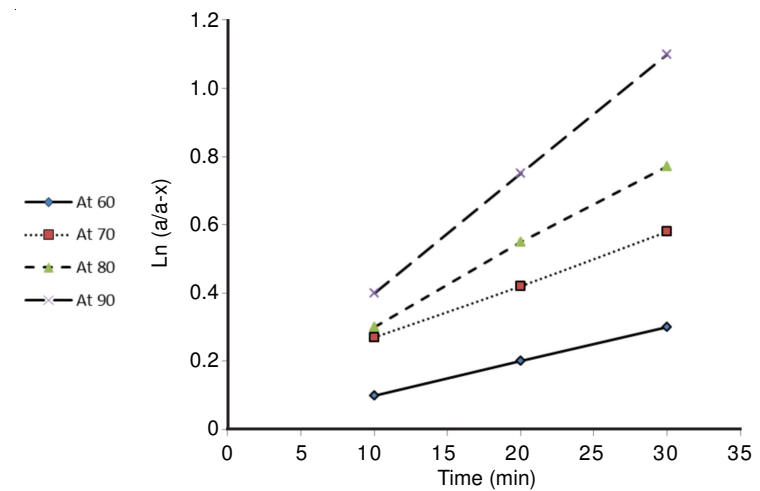

Fig. 3. Effect of different heating times with $0.1 \mathrm{M} \mathrm{NaOH}$ on the rate of degradation of candesartan cilexetil $(10 \mu \mathrm{g} / \mathrm{mL})$

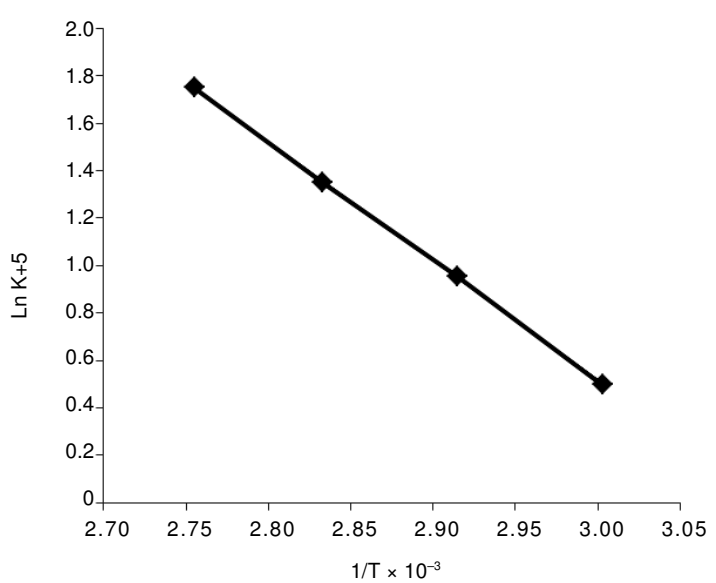

Fig. 4. Arrhenius plot for the degradation of candesartan cilexetil (10 $\mu \mathrm{g} /$ $\mathrm{mL}$ ) in $0.1 \mathrm{M} \mathrm{NaOH}$ 
The activation energy was calculated and found to be $10.08 \mathrm{Kcal} / \mathrm{mol}$. This value is in accordance with the reported value of activation energy required for the hydrolysis of esters ${ }^{33}$.

\section{Conclusion}

The proposed bivariate method provides simple, accurate and reproducible quantitative analysis for the determination of candesartan cilexetil in pharmaceutical tablets and in presence of its alkaline-induced degradation product, it is considered as a stability-indicating one. Thus, it can be used for the quality control of candesartan cilexetil in the commercial tablets with excellent application of content uniformity test. Moreover, the method is fast and feasible and has the advantages of being lower costing.

\section{ACKNOWLEDGEMENTS}

This project was supported by King Saud University, Deanship of Scientific Research, College of Science Research Center.

\section{REFERENCES}

1. K.L. McClellan and K.I. Goa, Drugs, 56, 847 (1998).

2. C.H. Gleiter, C. Jagle, U. Gresser and K. Morike, Cardiovas. Drugs Rev., 22, 263 (2004)

3. N. Ferreiros, S. Dresen, R.M. Alonso and W. Weinmann, J. Chromatogr. $B, \mathbf{8 5 5}, 134$ (2007).

4. L. Gonzalez, J.A. Lopez, R.M. Alonso and R.M. Jimenez, J. Chromatogr. A, 949, 49 (2002).

5. G. Iriarte, O. Gonzalez, N. Ferreiros, M.I. Maguregui, R.M. Alonso and R.M. Jimemez, J. Chromatogr. B, 877, 3045 (2009).

6. O. Gonzalez, G. Iriarte, N. Ferreiros, M.I. Maguregui, R.M. Alonso and R.M. Jimenez, J. Pharm. Biomed. Anal., 50, 630 (2009).

7. S. Mehta, R.P. Shah, R. Priyadarshi and S. Singh, J. Pharm. Biomed. Anal., 52, 345 (2010).

8. D.V.S. Roa, P. Radhakrishnanand, M.V. Suryanarayana and V. Himabindu, Chromatographia, 66, 499 (2007).

9. L.-J. Zhou, W. Dai, L.-H. Gu, Y.-J. Wang, Z.-Y. Huang and J.-Y. Liang, Fudan Univ. J. Med. Sci., 35, 552 (2008).
10. H. Stenhoft, P.O. Lagerstrom and C. Andersen, J. Chromatogr. B, 731, 411 (1999).

11. N. Erk, J. Liq. Chromatogr. Rel. Technol., 26, 2581 (2003).

12. S.S. Qutab, S.N. Razzaq, M. Asfag, Z.A. Shuja and I.U. Khan, Acta Chromatogr., 19, 119 (2007).

13. A.E.M. Khedr, King Abdulaziz Univ. Med. Sci., 15, 3 (2008).

14. S. Hillaert and W. Van den Bossche, J. Chromatogr. A, 979, 323 (2002).

15. S. Hillaert and W. Van den Bossche, J. Pharm. Biomed. Anal., 31, 329 (2003).

16. S. Hillaert, T.R.M. De Beer, J.O. De Beer and W. Van den Bossche, J. Chromatogr. A, 984, 135 (2003).

17. M. Zhang, F. Wei, Y.F. Zhang, J. Nie and Y.Q. Feng, J. Chromatogr. A, 1102, 294 (2006).

18. B. Dogan, B. Uslu and S.A. Ozkan, Pharmazie, 59, 840 (2004).

19. I. Suslu, N. OzaltIn and S. AltInoz, J. Appl. Electrochem., 39, 1535 (2009).

20. I. Suslu, N. OzaltIn and S. AltInoz, J. Assoc. Off. Anal. Chem. Int., 93, 562 (2010).

21. B.H. Mehta and S.B. Morge, J. Planar Chromatogr. Modern TLC, 21, 173 (2008).

22. N.A. Charoo, M. Bashir, E. Abdalla and K.I.H. Ali, Anal. Lett., 42, 2232 (2009).

23. N. Erk, Pharmazie, 58, 796 (2003).

24. M. Stolarczyk, A. Maslanka, J. Krzek and J. Milczarek, Acta Poloniae Pharm. Drug Res., 65, 275 (2008).

25. ICH, Stability Testing of New Drugs Substances and Products International Conference on Harmonization, Geneva (1993).

26. P.L. Lopez-deAlba, L.L. Martinez, K.W. Kaczmarmarzyc, K. Wrobel and J.A. Hernandez, J. Anal. Lett., 29, 487 (1996).

27. P.L. Lopez-de-Alba, L.L. Martinez, K.W. Kaczmarmarzyc, K. Wrobel and J.A. Hernandez, Bol. Soc. Chilena Quim, 41, 111 (1996).

28. D.L. Massart, B.G.M. Vandeginste, S.N. Deming, Y. Michotte and L. Kaufman, Chemometrics A Textbook, Elsevier, Amsterdam, p. 124 (1988).

29. F.H. Metwally, Spectrochim. Acta A, 69, 343 (2008).

30. ICH.Q2 (R1) Validation of Analytical Procedures: Test and Methodology, International Conference on Harmonization, Geneva (2005).

31. J.C. Miller and J.N. Miller, Statistics for Analytical Chemistry, EllisHowood New York, edn. 4, p. 115 (1993).

32. The United States Pharmacopeia 30, The National Formulary, 25, (2007):US Pharmacopeial Convention; Rockville, MD, Electronic version.

33. K.A. Conners, G.L. Amidon and L. Kennon, In Chemical Stability of Pharmaceuticals, John Wiley \& Sons, New York, p. 20 (1979). 